\title{
SOME REMARKS ABOUT THE SUMMER PERIOD IN HITTITE ANATOLIA
}

\author{
Serkan Demirel*
}

\begin{abstract}
Öz
Hititçe çivi yazılı metinlerde yaz mevsiminin var olup olmadığ yazın gerçekleştirilen tarımsal faaliyetler için kullanılan BURU ${ }_{14}$ kelimesinin aynı zamanda yaz mevsimi için de kullanıldığını iddia etmişlerdir. Bu makalenin amacı Hitit takviminde ayların sıralanışını açıklayarak söz konusu öneriyi desteklemek ve yaz mevsiminin başlangıç ve bitiş tarihlerine ilişkin tespitler yapmaktır. Ayrıca Anadolu'daki geleneksel halk takvimlerinde kullanılan terminoloji ile yaz mevsimine ilişkin Hititçe metinlerde kullanılan kelimeler arasındaki benzerliklere dikkat çekmektir. Zira Anadolu halk takvimlerinde hasat zamanı olarak adlandırılan dönem Hitit takviminde benzer bir isimle anılıyor ve yaz mevsiminin başlangıç ve bitiş tarihlerini gösteriyor olabilir.
\end{abstract}

Anahtar Kelime: Hitit, çivi yazılı metinler, yaz mevsimi, BURU ${ }_{14}$, Anadolu, halk takvimi

\begin{abstract}
There is an uncertainty about the naming or presence of summer season in Hittite cuneiform texts. However, some scholars claimed that certain agricultural activities in summer written as BURU 14 in Hittite cuneiform texts indicate the summer period. The purpose of this article is to support this argument by explaining the sequence of the months in the Hittite calendar and to make determinations about the start and end dates of the summer season. It is also to draw attention to the similarities between the terminology used for the summer in traditional calendars in Anatolia and the words used for the summer period in the Hittite cuneiform texts. The period called harvest time in Anatolian traditional calendars may be referred to by a similar name in the Hittite calendar and it may indicate the beginning and end dates of the summer season.
\end{abstract}

Keywords: Hittite, cuneiform texts, summer period, BURU ${ }_{14}$, Anatolia, traditional calendars

\footnotetext{
* Asst. Prof., Karadeniz Technical University, Department of Archaeology, Trabzon. E-mail: serkandemirel@ktu.edu.tr (Makale Gönderim Tarihi: 20.09.2017 - Makale Kabul Tarihi: 04.11.2017)
} 
The Hittites were multicultural and multilingual society who lived in Anatolia from the 17th century until the end of the 13th century BC. From their homeland in the Kizılirmak basin, the Hittites partially dominated Anatolia and Northern Syria. In this period, along with the Hittites, Hattians, Hurrians, Luwians existed in this region. Hittites who have dominated the indigenous people as occupant have established friendly or hostile relations with the other Anatolian communities. As a result of these relations, Hittites formed a mixed culture by adopting the cultural accumulation existing in Anatolia.

The Hittites were influenced by Mesopotamian and Anatolian traditions in astronomy/astrology as well as in many other areas. A small number of texts about astrology found in Boğazköy show the Babylonian traditions. ${ }^{1}$ However, these texts are far from proof that the tradition of Mesopotamian astronomy is accepted by the Hittites. Calendars are based on natural conditions and each area has a changing calendar conditions, depending on climatic and agricultural activities in particular. For this reason, even if there is an influence, a merger with the Anatolian calendar tradition should be the subject.

It is not clear that the Hittites can distinguish between astronomy and astrology and they probably observed movements of the celestial bodies. However, the Hittites tended to perceive the world within the framework of faith and it is more realistic that these observations were made with a religious understanding. Moon and sun eclipse are often used for prophetic purposes. ${ }^{2}$ When considering the Hittites, religion is a very major factor in this topic. Solar, lunar and astral cults represented the some celestial bodies. Because of this reason, it can be said that the astronomy in the Hittites remained on the theological level.

The Hittite heartland is a relatively high altitude and today it has semiarid climate. The agricultural possibilities that can be practice in this region are limited and dry farming is the only option except for river beds areas. Actually, dry farming is the most common type of agriculture in Anatolia. Around 19\% of agricultural areas can be irrigated. The proportion of areas that could be irrigated in the past was probably less and should have been stretching across wide river valleys. The natural environment of Anatolia has not changed dramatically over the past two thousand years and perhaps even longer, the traditional modes of land use by the rural communities living in Anatolia should not be so different from the ancient communities. In semi-arid regions, the risk

\footnotetext{
${ }^{1}$ Weidner 1923, 1-8. Beckman 2002, 35-42. The astrological materials reached Hattuša reflect Babylonian originals of varing dates. Hurrian influences remain possible but are very difficult to identify in the material. Westenholz 1993, 233-235. For the lists of star names from Mesopotamia found in Boğazköy, see; Weidner 1914, 17-21; Weidner 1915: 60-62.

${ }^{2}$ Kammenhuber 1976, 155ff; Riemschneider, 2004.
} 
of not being able to receive the crops that the Anatolian farmers of the present day faced from time to time must have happened to the farmers of the old times. ${ }^{3}$ Dry farming practices largely depend on climate. Rainfall during certain periods of the year is important for this kind of agriculture. The observation of weather conditions and their periodic recording have shaped traditional calendars. Agricultural activities based on climate conditions can be maintained through these calendars. The Hittite calendar can be expected to have a strong religious orientation. A large number of festivals and cult visits throughout the year should be part of the calendar. However, in this calendar, agricultural practices must also be followed in connection with the religious dimension. ${ }^{4}$ Because, in the Hittite era, the economic life of the people who lived in Anatolia was largely based on agriculture.

The full understanding of the Hittite calendar is a very difficult issue and obviously we are quite far from this. The Hittite texts contain limited information about the subject. It is not certain that the Hittites used the moon or solar-based calendar. But the fact that the movement of the moon and its eclipse were frequently used in dating by the Hittites. ${ }^{5}$ Similar signs can be seen in Hittite law. ${ }^{6}$ But if the Hittite calendar was based on the moon's cycles, it would be 11 days per year shorter than the solar calendar. In these circumstances, the months must be moving within the calendar. However, it is understood that the months are fixed depending on the seasons. ${ }^{7}$ For these reasons, it can be assumed the Hittites used a lunisolar calendar. ${ }^{8}$ It can be said that the Hittite calendar is predominantly a cult calendar and therefore the festivals (celebrated monthly, annually and longer periods) were important elements in the calendar. ${ }^{9}$

\footnotetext{
${ }^{3}$ Yakar 2007, 157-168; Hoffner 2003, 95-118. As pointed out in $\S 183$ of Hittite laws, the most expensive land is irrigated fields. (KBo 6.26 III 3-7) Hoffner 1997, 146. The agriculture in Anatolia during the Hittite period was not much different from the practices in the recent period. For details on agricultural practices in the Hittites, see. Ertem 1973, 84-89; Klengel 1986: 23-31.

${ }^{4}$ In the ancient states where agriculture is the main source of income, their political system, ideology and mytology focused on the order of the annual farmer's cycle. Christopher 1995, $175 \mathrm{ff}$.

${ }^{5}$ Riemschneider, 2004; Güterbock 1988, 164-171.

${ }^{6}$ [tak]ku MUNUS-aš ELLI šarhuuanduššuš kuiški p[é]š[šiy]anzi [takku] ITU 10.KAM "If anyone causes a free woman to miscarry, [if] it is her tenth month” (KBo 6.3 I 40-41) Law § 17: Hoffner 1997 28-29. The statement of indicates that a measurement is made based on the lunar calendar. Erginöz 2008, 209.

${ }^{7}$ KUB 10.78 VI 8-10+20.25 IV 2-5; Popko 1994, 304. KUB 38.32 Obv. 8; Chicago Hittite Dictionary (P): 123-124. See, lines attached footnote 15 and 18.

${ }^{8}$ Belmonte and Garcia 2014, 118.

9 The Hittite festivals and cult visits throughout the year and their calendars essays, see. Güterbock 1970, 175-180; Houwink ten Cate 1986, 95-110; Houwink ten Cate 1988, 167-194.
} 
Particular attention was paid to the celebration of festivals right on time. ${ }^{10}$ In conjunction with these festivals in the Hittite calendar, agricultural activities were also a decisive factor. From spring to autumn, the periods of sowing and reaping were used to time keeping. ${ }^{11}$ The least known period in the Hittite calendar is the summertime in which agricultural activity is intense. However, it is probable that some agricultural activities have been used in the name of the period in question. ${ }^{12}$ This can be quite normal. In societies where agricultural production is predominant, agricultural activities can be included in calendars such as crop schedule.

We do not encounter any names of months in the Hittite cuneiform texts. The months are usually named according to the order in the year. In the Song of Kumarbi, the months range from the first to the tenth; ITU 1.KAM ITU 2.K[(AM IT)]U 3.KAM [IT]U 4.KAM ITU 5.KAM ITU 6.KAM ITU 7.KAM ITU 8.KAM ITU 9.KAM p[ait] nu [(IT)]U 10.KAM tiyat "The first, second, and third [mo]nths. The fourth, fifth, and sixth months passed. The seventh, eighth, and ninth months $\mathrm{pa}$ [ssed] and the tenth month entered" (KUB $24.8+34.60$ III 1-3). ${ }^{13}$ It is mentioned about eleventh month of the year in Hittite

With regard to the significance of the festivals in the Hittite calendar in the agricultural season, see. Demirel 2017, 21-32.

${ }^{10}$ In the text on the duties of priest and the temple officials, a translation of the chapter on the subject is as follows: "Now you who are temple officials in (the temple), if you do not celebrate the festivals at the time of the festivals, if you perform the festival of the spring in the autumn but celebrate the festival of the autumn in the spring, and if at the proper time for performing the festival the man who is performing it comes and approaches you the priests, anointed priests, and mothers of god and you the temple officials and embraces your knees (saying): The harvest is before me, or a marriage, or a journey, or some other business; now do me a favor; let this business first be finished for me. But when this business of mine is past I shall perform the festival just so" (KUB 13.4 Vs. 57-68). Süel 1985, 46, 48. Sturtevant 1934, 376-378. Also, see Taggar-Cohen 2006, 117.

${ }^{11}$ These periods of the year were most likely celebrated with festivals of AN.TAH.ŠUM and nuntarriyašhaš. AN.TAH.ŠUM festival, see Güterbock 1960, 237-245. nuntarriyašhaš festival, see Nakamura 2002. These festivals were celebrated for sowing of seed and harvesting time. Güterbock 1964, 54-73. The importance of timing in religious and agricultural activities can indicate that astronomical observations are being made by the Hittites. An example can be given to support this situation. The SANGA priest of Sun-Goddes of the Earth regularly slept "under the stars" at the temple courtyard and he was may be making astronomical observations so that the festivals can be done on time. Belmonte and Garcia 2014, 116.

${ }^{12}$ Landsberger 1949a 293. Güterbock 1967, 141-150. Hoffner 1974, 13-14.

${ }^{13}$ Siegelova 1974, 10. mahhanma ITU 3.KAM t[iyazzi "But when the third month a[rrives]" (KBo 17.65 Rev. 41) Beckman 1983, 142. takku INA ITU 4.KAM ${ }^{\mathrm{d}}$ EN.ZU-a kattanda pauwas mēhuni aki "If the moon is eclipsed in the fourth month at the time of its setting" (KUB 29.9 VI 9-10) Chicago Hittite Dictionary (L-N): 240. [m]ān INA ITU.4.KAM d SIN-aš puš[za n]aššu gašza kiša naššu x [L]Ú-aš kuiški aki mān INA ITU 5.KAM d SIN-aš pušza girēzza uizzi "If the moon is eclipsed (?) in the fourth month, there will be either famine, or some man will die. If 
laws; mān URU Arinna 11.ITU-aš tezzi "in Arinna when the eleventh month arrives" (KBo 6.2 II 61) ${ }^{14}$ It is referred that the twelfth month of the year corresponds to winter in the text of winter journey of the sacred hunting bag; $m \bar{a} n$ [ŠE ${ }_{12}$ ]-anti INA ITU 12.KAM ${ }^{\text {d.KUŠ }}$ kurš[aš] IA ${ }^{\mathrm{d}} \mathrm{U}{ }^{\mathrm{URU}}$ Zipalanda ANA

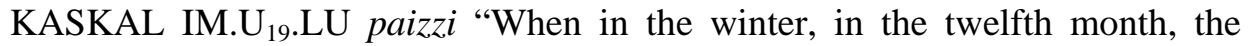
divine-hunting-bag of the Stormgod of Zippalanda goes on a journey south" (KUB 10.78 VI 8-10+20.25 IV 2-5). ${ }^{15}$ It is possible to see that the Hittites did not use a specific word for the month names and the months are named according to the order in the year. ${ }^{16}$

As can be understood from the texts, the Hittite calendar has twelve months, but there is not enough information about the duration of the months. However, the months have more or less equal lengths and probably consisted of about thirty days. It is not possible to say when the new year began in the Hittite calendar. However, the most accepted period is in the spring, the beginning of the agricultural season ${ }^{17}$ It is not clear how long the spring has lasted. But,

the moon is eclipsed (?) in the fifth month, a flood will come” (KUB 34.10 6-10) Chicago Hittite Dictionary (P): 398. takku INA ITU. 4.KAM ${ }^{\mathrm{d}}$ EN.ZU-as kattanda pa-a-u-wa-as mehuni $a k i$ "If there is a lunar eclipse in the fourth month at the time of (the moon's) going down" (KUB 29.9 IV 9-10) Chicago Hittite Dictionary (P): 32. mān ISTU ITU 6.KAM ISTU UD.21.KAM kuitman ${ }^{\mathrm{d}} \mathrm{SIN}$-as zinnattari "If the moon is eclipsed in the sixth month from the twenty first day" (KUB 8.1 II 11-12) Chicago Hittite Dictionary (L-N): 457-458. [... I]NA ITU.7.KAM armahhuas māla šipanti "i]n the seventh month performs the māla (-offering) of pregnancy" (KBo 17.65 Obv. 6) Beckman 1983, 132. mān ANA MU-TI ITU 8.KAM tiyazi ANA ITU 8.[KAM UD.x. KAM tiyazi] nu ANA ${ }^{\mathrm{d}} \mathrm{U}{ }^{\mathrm{URU}}$ Halap ${ }^{d}$ Hebat ${ }^{\mathrm{URU}}$ Halap ${ }^{\mathrm{URU}} \mathrm{KU}$.BABBAR [...] EZEN E $_{4}$ púdahaš iyanzi "When in the year the eighth month arrives, and when in the eighth month [the Xth day arrives] for Teššb of Aleppo, Hepat of Aleppo[...] they perform the pudahaš festival in Hattuša” (KBo 14.142 II 5-7) Chicago Hittite Dictionary (P): 401. In the Hittite mythology, the Storm God, representing the harvest, is in power between June/July and

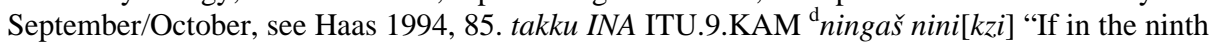
month a cloudburst breaks loose” (KUB 8.28 obv. 14-16) Chicago Hittite Dictionary (L-N): 445. ITU 10.KAM-ya EGIR-an paizzi "and the tenth month passes" (KBo 27.67 Rev. 9) Beckman 1983, 218.

${ }^{14}$ (KBo 6.2 II 61) Law § 50: Hoffner 1997, 61.

${ }^{15}$ Popko 1994, 304. INA ITU 11.KAM DUMU-aš miyari apaš DUMU-aš innarauešzi INA ITU 12.KAM DUMU-aš miyari apaš DUMU-aš LÚ ̌̌U.GI-ešzi "(if) in the eleventh month a child is born, this child will become strong; (if) in the twelfth month a child is born, this child will grow old” (KUB 8.35 Obv. 9) Beckman 1983, 14.

${ }^{16}$ The month names in Hittite have no religious occasion. del Monte 1987, 56. The months haven't specific name and they are named with the numbers starting from first month and ending in twelve months in the Anatolian countryside until quite recently, see Erginer 1984, 48.

17 "vernal equinox" Gurney 1952, 152. "spring”, see Bittel 1970, 108. Hoffner 1974, 12-14. "march", see Haas 1994", 85. The twelfth month of the year coincides with winter; (KUB 10.78 VI 8- 10 + KUB 20.25 VI 2-5) Popko 1994, 304. According to the some scholars, the festival of purulli was a New Year's ceremony; Haas 1994”, 696. Garcia Trabazo, 2002, 77. The 
thanks to a cult inventory text, it is known that the autumn corresponds to the eighth month of the year; GIM-an zēnas kišari ANA MU.KAM-TI ITU 8.KAM "When it becomes fall, (and) the eighth month in the year" (KUB 38.32 Obv. 8). ${ }^{18}$ In this case, the autumn probably began in September-October. ${ }^{19}$ Accordingly, the first eight months of the year were considered in spring and summer. The natural conditions within this period in central Anatolia are not evaluated in a single season. For this reason, it can be said that a few months back from the eighth month of the year should be in summer. Differences between seasons can be traced to changes in agricultural activities. The dissimilarity between spring and autumn is the harvesting of ripe crops and so the best date for the beginning of the summer may be the end of June. This period that begins with summer solstice is considered to be the beginning of summer and harvest season in Anatolia today. ${ }^{20}$

Three seasons are mentioned in Hittite texts, which are hamešhant (spring), zenant (autumn), and gimant (winter). ${ }^{21}$ Connected with fall, there are also some marks (BURU ${ }_{14}$ ) indicating summer. ${ }^{22}$ Some practices in agriculture and animal husbandry in Anatolia and the beliefs clustered around them have a large place in the formation of traditional calendars. ${ }^{23}$ Likewise, cultivation and harvesting practices may be associated with the naming of summer months in

festival was celebrated in spring; udniua māú šešdu nuwa udnē pahšanuuan ēšdu nu mān māi šešzi $n u{ }^{\text {EZEN }}$ purulliyaš iyanzi "Let the land grow (and) thrive, and let be land secure and when it (indeed) gorws (and) thrives, then they perform the festival of purulli" (KBo 3.7 I 5-7) Beckman 1982", 12. On the 11th day of AN.TAH.ŠUM festival, celebrated in the spring, there

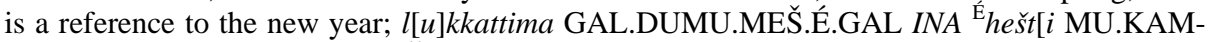
a]n pédai LUGAL-ušša EGIR-ŠU iaya[ttari nuk]an paizzi pittiyauuaš "Next day the chief of the palace attendants carries [the year] to the House of the Dead, and the king follows him" Güterbock 1960, 239.

${ }^{18}$ Chicago Hittite Dictionary (P): 123-124.

${ }^{19}$ It is reported that the Hittite king celebrated the nuntarriiaššaš feast in the autumn after returning from the expedition "When the king returned from the military campaign (in autumn) he performes the festival of nuntarriiaššaš" (KUB 9.16 I 1-2). Karasu 1988, 410. Nakamura 2002, 17. Accordingly, the date of return from campaign must be between September and November due to economic and climate conditions.

${ }^{20}$ Güner and Şimşek 1998, 134; Jakar 2007, 160-161.

${ }^{21}$ For the etymological review of these words, see: Goetze 1951, 467-576. There is not enough information about the etymology of the names of the seasons in Hittite cuneiform texts. It is suggested that the hamešha/hamešhant used for spring means "to growth" (Hoffner 1974, 15). There is a similar situation for the naming of the spring season in the Anatolian traditional calendars. Döltökümü Ay1/Fertility Month is used for the beginning of spring (March) in these calendars. Erginer 1984, 25

22 Landsberger 1949b, 293; Güterbock 1967, 141-150; Hoffner 1974, 13-14.

${ }^{23}$ The cultivation and sowing practices affected the traditional calendars in Anatolia, see Erginer 1984, 71-83. 
the Hittite calendar. In fact, there is no word for the summer season in the Hittite texts. However, when we look at the distribution of the seasons from the beginning of the year, it is understood that the summer season should also be on the calendar due to the agricultural conditions. It is possible that the summer season in Hittite era had been named with some agricultural practices as in the traditional calendars. The ideogram of BURU ${ }_{14}$ was used to express the harvest time and the summer season in Mesopotamian calendars. ${ }^{24}$ In a similar manner, it is argued that the ideogram of BURU $_{14}$ means "summer" in Hittite texts. ${ }^{25}$ Actually, the meaning of the ideogram is the harvest/crop and is often used in this sense in the texts. ${ }^{26}$ However, the ideogram was sometimes used as a period name in a year. In a text about the storm-god of Kuliwišna, it is stated that no matter what season, it must be worshiped in God; mān hameši mān BURU ${ }_{14}$ mān [...] gimmi "whether in spring, or harvest time, or [...] in winter" (KBo 15.32 I $3-4) .{ }^{27}$ The broken part of the text can be written as autumn/zeni $m \bar{a} n .{ }^{28}$ In an auspice text, ideogram of BURU ${ }_{14}$ is written between spring and autumn; $\left.m\right] \bar{a}[n$ ha]meši $\mathrm{BURU}_{14}$ mān zeni [... ÚL kui]tki tuqqari "whether in spring at harvest time or in fall [...] it does not matter” (KBo 32.123 III 14-15). ${ }^{29}$ In the mythos of disappearance of Hannahanna, BURU 14 referred as a season; hamešiyaz BABBAR-TIM wašš[aši] BURU ${ }_{14}-$ maz išharwand[a w]aššaši "in the spring you wear white, at harvest time you wear red" (KUB 33.54 ii 13-14+ KUB 33.47:1). ${ }^{30}$ In a mouthwashing ritual, the ideogram of BURU ${ }_{14}$ used for summer period; [ANA ${ }^{\mathrm{d} U T U-S ̌ I-] a ̄ t k a n ~} \mathrm{KA}_{\mathrm{X}} \mathrm{U}-a \mathrm{Z}{ }^{\mathrm{URU}}$ Zi[thara INA BURU ${ }_{14}$ p] arā aniyãuen "We copied it out [in the summer in] Zi[thara] from the mouth [of His

\footnotetext{
${ }^{24}$ Landsberger 1949a, 248; von Soden 1965, 183.

${ }^{25}$ Harvest/harvest season/summer, see Hoffner 1974, 24-26. "harvest/harvesting period”, see Ünal 2016, 720; Güterbock 1967, 141-150; Tischler 2001, 216.

${ }^{26}$ KUR-e anda mašaš parai BURU ${ }_{14}$.HI.A karāpi "the locust will appear in the land and devour the crops” (KUB 8.1 II 16-17) Chicago Hittite Dictionary (P): 134. BURU ${ }_{14}$ mišariš kara[pi] "the grain weevil will devou[r] the harvest" (KUB 8.1 III 19): Hoofner 1974, 24-25.

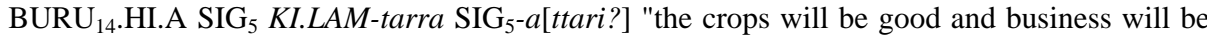
good" (KUB 34.14 Rev. 4): Chicago Hittite Dictionary (L-N): 50. BURU 14 iššer KI.LAM SIG 5 GAR-an "the harvest will prosper, and business will be good" (KUB 4.63 III 21) Chicago Hittite Dictionary (L-N): 50. [(KUR-e)-aš BU]RU ${ }_{14} \cdot \mathrm{HI}_{\text {.A }} \mathrm{SIG}_{5} a n-d[a]$ "the crops of the land will be good" (KUB 8.4 2) Chicago Hittite Dictionary (L-N): 51. "miyantan BURU ${ }_{14}$ KURanza kārapi" "The land will eat an abundant harvest" (KUB 29.11 II 10) Chicago Hittite Dictionary (L-N): 235. BURU ${ }_{14}{ }^{\mathrm{MES̆}}$ ua[m]ukan piran naššu kušata naššu KASKAL-aš našma tamai kuitki uttar "Harvests are ahead of me or a wedding or a journey or other business" (KUB 13.4 II 58-60) Süel 1985, 48.

${ }^{27}$ Güterbock 1967, 142; Chicago Hittite Dictionary (L-N): 230.

${ }^{28}$ Hoffner 1974, 13; Puhvel 1991, 73.

${ }^{29}$ Starke 1985, 309.

${ }^{30}$ Laroche 1965, 61-178.
} 
Majesty]” (KBo 23.6 9-10). ${ }^{31}$ In instructions by Arnuwandas I for provincial governors ( $B \bar{E} L M A D G A L T I)$, tasks that need to be done are divided into winter

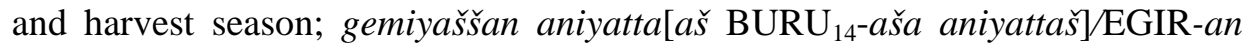
arhut "occupy yourself with the tasks of winter [and the tasks of harvestseason]" (KUB 13.1 Rev. IV 12-13). ${ }^{32}$ In the vow of Puduhepa, it is requested that the debtors pay their debts in the harvest season; nu kuiš kuedani arzananza $\overline{e s ̌ t a ~ n u s ̌ s ̌ i ~ N U M U N ~}{ }^{\mathrm{HIA}}$ kuit [(an)]iyat naššiyaškan EGIR-anpát [...] para A-NA BURU $_{14}$ halkin pai "Whoever is supported by another and has had seed paid out to him shall pay it (all) back to him (in the form of) grain at the next harvest season (The vow of Puduhepa, III 28-31). ${ }^{33}$ It can be said that the difference between spring and summer in the Hittite calendar is harvesting. ${ }^{34}$ For this reason, it may be more accurate to translate as the summer period the parts of the texts written with $B_{\text {BRU }}$. The evaluation of the ideogram as a summer season is suitable both in terms of Hittite texts and traditional calendars in Anatolia.

Whatever the natural and cultural environment, almost every land has its own unique calendar. Calendars were a source of deep-rooted and rich vernacular tradition consisting of some cultural elements influenced by the country's natural environment. Traditional calendars divide years differently compared to the prevalent calendars. In these calendars, the days are named differently and assumed good and bad characteristics of the climate for some periods of the year. According to the popular beliefs, failure to comply the public calendars which are products of long-term experience and knowledge, and not to act in the direction it shows, causes great harm to individuals and societies. Because traditional calendars are the product of the natural and

${ }^{31}$ Chicago Hittite Dictionary (P): 117. “ANA ${ }^{\mathrm{d}} \mathrm{UTU}$-ŠI-ia-at-kan INA ${ }^{\mathrm{URU}}$ Zithara INA BURU ${ }_{14}$ $\mathrm{KA}_{\mathrm{X}} \mathrm{U}-a z$ parā aniyauen" "For His Majesty we wrote it (...) "from (his) mouth" in the city of Zithara at harvest time/summer” (KUB 29.8 IV 38-39) Chicago Hittite Dictionary (P): 117.

32 von Schuler 1967, 24; Chicago Hittite Dictionary (ك̌-1): 150. A similar comparison was made

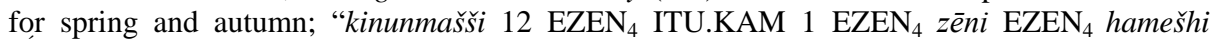
LÚSANGA IŠTU É-ŠU ēššai" "Now for him (the deity) the priest will celebrate using his own means twelve monthly festivals, one autumn festival (and one) spring festival”, (KUB 42.100 IV 22-23) Chicago Hittite Dictionary (P): 290.

33 Otten 1965, 30; Hoffner 1974, 27. A similar debt payment in the harvest period is also found in Kültepe texts; (o/k 46 11-13) Albayrak 1996, 7.

${ }^{34}$ Similarly, the harvest periods can also be seen in Mesopotamian calendars. In the Nippur calendar, the first and last month of the year are associated with harvest and sickle (grain and barley). The first month is called the harvest period ( ${ }^{\text {iti }}$ bára-zag-gar=Nisannu [March-April]) and the twelfth month is related with barley harvest "itiťe-kin-du,", see Cohen 1993, 80-83, 119-124). In the early Semitic calendar, I-rí-sá, fourth month of the year translates as sowing. Pettinato 1977, 283. In the pre-Sargonic period, ${ }^{\text {iti }}$ ezem ${ }^{\mathrm{d}}$ Nin-gír-su-ka buru $\left(\mathrm{Gana}_{2}\right)$ probably refers harvest, see Krechner 1973, 247. 
cultural environment in which they are formed. In Anatolia, the traditional calendars/local calendars were used until recently. But today it is known as a folkloric material and has been forgotten. These calendars are part of the natural and cultural environment influenced by climatic conditions, economic, religious and social events. Especially, it can be seen that the economic factors are more dominant in pre-Islamic calendars. The type of production and some elements of social structure are the basic elements of these calendars. ${ }^{35}$ In traditional calendars, the names of the seasons are usually ignored and the periods are calculated without paying attention to the equal division of the year. In these calendars, the months that correspond to summer, are named with agricultural activities.

In the Anatolian traditional calendars, the summer generally begins in June and continues until September. The harvest period is also compatible with these dates. The seeds were planted in the fall season and the sprouts emerged in the spring. Spring rains following the dry season in March (April-May) prepare the ideal environment for the full ripening of the crop. From the end of May, the spikes do not need the pour to grow during the summer months. The rains in this period prevent the development of grains by cooling the land. But in June, a moderate wind is useful to ensure that the grains mature and dry. ${ }^{36}$ At the end of this process, the harvesting and its subsequent threshing periods generally begin in June/July and continue until September/October in Anatolia. Barley and oats are harvested in the end of June, wheat is harvested in the middle of July, and some crops will continue to be harvested until the end of August in the middle Anatolia. ${ }^{37}$ These periods influenced the traditional calendars. The summer season started in summer solstice (June 21/in the fourth week) and ended in autumnal equinox (September 23) in these calendars. ${ }^{38}$ Depending on the geographical location, the first month in the summer is called "Orak/Ekin Biçme Ayı" (Sickle//Harvesting Month) in some region of Anatolia and the following summer month is called "Harman/Çayır Ayı" (Treshing Month). ${ }^{39}$ It can be argued how far past of traditional calendars in Anatolia have

${ }^{35}$ Erginer 1984, 22-26; Kırzıoğlu 1971, 5275-5277.

36 Jakar 2007, 160-161; Güner and Şimşek 1998, 134.

${ }^{37}$ Erginer 1984, 79-83.

${ }^{38}$ The summer starts in the fourth week of June and autumn starts in the Mid-September or the beginning of November. Jakar 2007, 160; Güner and Şimşek 1998, 134.

39 "Orak Ayı" Sickle/Reap Month=July, Çayır Ayı/Treshing, Meadow or Harvest Month=August, see Erginer 1984, 25. In North Anatolia, these periods are one month late and Harvest Month is also called Rotten Month "Çürük Ayı", see Demir 2012, 5-21. Düzgün 2014, 223-256. August is called "Harman Sicağı"/Harvest Heat. Koç and Keskin 2001, 4. In Anatolia, the harvested agricultural product gives its name to the relevant month. In northern Anatolia, June is called as "Kiraz Ay1" (Cherry Month), and in the western Anatolia, September is called as "Incir or 
gone, but it should be noted that people living in the same geography have similar needs. Until recently, agriculture in Anatolia was done with classical methods. Sowing, reaping and harvesting of the products were carried out in the same way and periods as in the past.

\section{Conclusion}

It is not possible to explain the nature of the Hittite calendar. Thanks to the information obtained from a small number of cuneiform texts, it can be partially understood how the Hittites divided the year. The missing parts of this calendar can be understood from the traditional calendars used in Anatolia until recently. In this article, the interest of the researchers was tried to withdraw in this topic.

It can be seen that the months of the Hittite calendar are based on the seasons and are named according to the order in the year. Seasons are characteristically separated from each other. Although there are many religious festivals and excursions visits throughout the year, economic activity is more decisive in this calendar, particularly in the summer months when agricultural activities are at its peak. In this case, it is likely that these activities were also used in the naming of certain periods in the calendar.

The increase in agricultural production at the beginning of the harvesting season demonstrated the difference between summer and spring seasons. For this reason, it may be a correct evaluation to translate the ideogram of $\mathrm{BURU}_{14}$ as summer in the Hittite cuneiform texts. The absence of a special word for the summer season can be regarded as a normal, because the situation is similar in the traditional calendars. It is known that the word of harvest is generally used for summer and the threshing is also used for fall in Anatolian traditional calendars. Possibly it can be said that during the Hittite period the summer season began in June, when the beginning of the harvesting, as in the traditional calendar in Anatolia, and continued until September-October, the eighth month of the Hittite calendar known as the threshing time.

Üzüm Ayı" (Fig or Grape Month). Mihçığlu 1980, 186-189. Sarı 1971, 51-68. Düzgün 2014, 247. Demir 2012, 11. "In the new calendar, the Cherry Monthr is called June. The farmers use their sickle in the June 12. This day is the solstice. The solstice lasts three days. (The seventh month of the year is the sickle month) The sickle work continues on this month.” Özergin 1969, 5275-77. 


\section{BIBLIOGRAPHY}

Albayrak 1996

Beckman 1982

Beckman 1983

Beckman 2002

Belmonte and Garcia 2014

İrfan Albayrak, "Koloni Çağında Yerli Bir Bayan Adı “Madawada.”, III. Uluslararası Hititoloji Kongresi Bildirileri, Çorum, September 16-22, Ankara, pp.1-14.

Gary Beckman, "The Anatolian Myth of Illuyanka", Journal of Near Eastern Studies 14, pp. 11-25.

Gary Beckman, Hittite Birth Rituals. Wiesbaden: Harrassowitz, StBoT 29.

Gary Beckman, "The Babilili-ritual from Boğazköy (CTH 718)", Recent Development in Hittite Archaeology and History, edited by K. A. Yener, H. A. Hoffner, S. Dhesi, Winona Lake, pp.35-42.

Juan Antonio Belmonte and A. Cesar Gonzalez Garcia. “Astral Symbolism and Time Keeping in the Hittite Culture.” Paper presented Proceeding of the Eight International Congress of Hittitology, Warsaw, Septembre 5-9, 2011, pp. 110-123.

Bittel 1970

CHD L-N

CHD P

CHD Š-1

Christopher 1995

Cohen 1993

Demir 2012

Demirel 2017

Düzgün 2014
Kurt Bittel, Hattusha, The Capital of the Hittites. New York: Oxford University Press.

Chicago Hittite Dictionary, Vol. L-N, edited by H. G. Güterbock and H. A. Hoffner, Chicago, Illinois, Oriental Institute, 1989.

Chicago Hittite Dictionary, Vol. P, edited by H. G. Güterbock

Chicago Hittite Dictionary, Vol. Š, Fascicle 1, edited by H. G. Güterbock, H. A. Hoffner and Theo P. J. van den Hout, Chicago, Illinois, Oriental Institute, 2002.

J. Eyre Christopher, "The Agricultural Cycle, Farming and Water Management in the Ancient Near East”, In Civilizations of the Ancient Near East, edited by Jack Sasson, pp.185-188. Screibner, New York.

Mark E. Cohen, Cultic Calendars of the Ancient Near East. Bethesda/Maryland: CDL Press.

Necati Demir, "Trabzon Yöresinde Zaman, Halk Takvimi ve Sayılı Günler”, Zeitschrift für die Welt der Türken 4, no. 1, pp. 5-21

Serkan Demirel, “An Essay on Hittite Cultic Calendar, Based Upon the Festivals”, Athens Journal of History 3, no. 1, pp. 2123.

Ülkü Kara Düzgün, “Giresun Halk Takvimi, Sayılı Günler ve Bunlara Bağlı İnanış ve Uygulamalar”, Karadeniz, Özel Sayı, pp. 223-256. and H. A. Hoffner, Chicago, Illinois, Oriental Institute, 1997. 
del Monte 1987

Erginer 1984

Erginöz 2008

Ertem 1973

Garcia 2002

Goetze 1951

Gurney 1952

Güner 1998

Güterbock 1960

Güterbock 1964

Güterbock 1967

Güterbock 1970

Güterbock 1988

Haas 1994

Hoffner 1974

Hoffner 1997

Hoffner 2003
Guiseppe, F. del Monte, "Il mese hittita." in Studi di historia e di filologia anatolica dedicati à Giovanni Pugliese Carratelli, edited by F. Imparati. 51-56. Elite, Florence.

Gürbüz Erginer, Uşak Halk Takvimi ve Halk Meteorolojisi, Ankara: Türk Tarih Kurumu Basımevi.

Gaye Şahinbaş Erginöz, "Hititlerde Astronomi Bilgisine ve Hitit Takvimine Bir Bakış", Osmanlı Bilimi Araştırmaları 9, no. 1-2, pp. 199-213.

Hayri Ertem, "Hititçe Çivi Yazılı Metinlere Göre 'Hititlerde Tarla Tarımı”, Paper presented Türk Tarih Kongresi 7, Ankara, pp. 84-89.

Garcia Trabazo, José Virgilio, Textos Religiosos Hititas: Mitos, Plegares y Rituales. Madrid: Tapa Blanda.

Albrecht Goetze, "On the Hittite Words for 'Year' and the Seasons and for 'Night' and 'Day"', Language 27, no. 4, pp. 467-576.

Oliver Robert Gurney, The Hittites. Melbourne, London, Baltimore: Penguin Books.

İbrahim Güner and Oğuz Şimşek, “Iğdır'da Halk Takvimi ve Halk Meteorolojisi”, Türk Coğrafya Dergisi 33, pp. 129-135.

Hans Gustav Güterbock, "An Outline of AN.TAH.ŠUM Festivals”, Journal of Near Eastern Studies 19, pp. 237-245

Hans Gustav Güterbock, "Religion und Kultus der Hethiter”, Hostoria Einzelschriften 7, pp. 54-73.

Hans Gustav Güterbock, "Lexicographical notes III," Revue hittite et asianique 25, no. 81, pp. 141-150.

Hans Gustav Güterbock, "Some Aspect of Hittite Festivals”, Presented papers Actes de la XVII Recontre Assyrologique Internationale, Brussels, pp. 175-180.

Hans Gustav Güterbock, "Bilingual Moon Omens from Boğazköy." in A Scientific Humanist: Studies in Memory of Abraham Sachs, edited by Maria dej Ellis, 164-171. Univ of Pennsylvania Museum.

Volkert Haas, Geschichte der Hethitischen Religion. Leiden: E. J. Brill, Handbuch der Orientalistik 15.

Harry A. Hoffner, Alimenta Hethaeorum, Food Production in Hittite Asia Minor. New Heaven: American Oriental Society,. Harry A. Hoffner, The Laws of the Hittites. Leiden, New York, Köln: Brill.

Harry A. Hoffner, "Daily Life Among the Hittites", in Life and Culture in the Ancient Near East. Edited by Richard Averbeck, Mark W. Chavalas and David B. Weisberg, pp.95-118. Betheshda MD, CDL Press. 
Houwink ten Cate 1986 H. J. Houwink ten Cate,, "Brief Comments on the Hittite Cult Calendar: The Outline of the AN.TAH.ŠUM Festival”, in Kaniššuwar, A Tribute to Hans Gustav Güterbock on his Seventhy-Fifth Birthday, edited by G. Beckman, R. Beal, G. Mc Mahon, Chicago, pp. 95-110.

Houwink ten Cate 1988 , H. J. Houwink ten Cate, "Brief Comments on the Hittite Cult Calendar: The Main Recension of the Outline of the nuntarriyašhaš Festival, Especially Days 8-12 and 15'-22'”, in Documentum Asiae Minoris Antiquae, Wiesbaden, pp.167-194.

Kammenhuber 1976

Annelies Kammenhuber, Orakelpraxis, Träume und Vorzeichenschau bei den Hethitern. Heidelberg: Universitätsverlag C. Winter.

Karasu 1988 Cem Karasu, “nuntarriiaššaš Bayramında Hitit Krallarının Kült Gezileri”, Belleten 52/203, pp. 407-428.

Kırzıoğlu 1971 M. Fahrettin Kırzıoğlu, "Halk Takvimi, Çevre Ağzı, Yemiş, Ağaç ve Ot Adları” Türk Folklor Araştırmaları 262, pp. 52755277.

Klengel $1986 \quad$ Horst Klengel, “The Economy of the Hittite Household (É)”, Oikumene, Studia et Historiam Antiquam et Orientalem Spectantia, edited by I. Hahn, L. Kakosy, G. Komoroczy, E. Maroti, J. Sarkady, Budapest, Akademiai Kiado, pp. 23-31..

Koç and Keskin 2001 Talat Koç and Nazan Keskin, "Uzunköprü’de Halk Takvimi ve Sıcaklık İlişkisi”, Balıkesir Üniversitesi Sosyal Bilimler Dergisi 5, pp. 1-15.

Krechner $1973 \quad$ Joachim Krechner, "Neue Sumerische Rechtsurkunden des 3. Jahrtausends”, Zeitschrift für Assyriologie und Vorderasiatische Archäologie 63, pp.145-271.

Laroche 1965 Emmanuel Laroche, "Textes mythologiques hittites en transcription. I. Mythologie anatolienne”, Revue hittite et asianique 23, no. 77, pp. 61-178.

Landsberger 1949a Benno Landsberger, “Jahreszeiten im Sumerisch-Akkadischen” Journal of Near Eastern Studies 8, no. 3, pp. 248-272.

Landsberger 1949b Benno Landsberger, "Jahreszeiten im Sumerisch-Akkadischen(Concluded)”, Journal of Near Eastern Studies 8, pp. 273-297.

Mihçıŏlu 1980

Nakamura 2002

Cemal Mihçıŏlu, “Ay Adları” TD 342, pp. 186-189.

Mitsuo Nakamura, Das Hethitische nuntarriyašha-Fest. Leiden: Publication de l'institute Historique et Archéologique Néerlandais de Stambul 94.

Otten 1965

Özergin 1969 Heinrich Otten, Das Gelübte der Königin Puduhepa an die Göttin Lelwani. Wiesbaden: Harrassowitz, StBoT 1.

M. K. Özergin, "Halk Takviminde Aylar”, Türk Folklor Araştırmaları 238, pp. 5275-5277. 
Pettinato 1977

Popko 1994

Puhvel 1991

Riemschneider 2004

Sar1 1971

Siegelová 1974

Starke 1985

Sturtevant 1934

Süel 1985

Taggar-Cohen 2006

Tischler 2001

Ünal 2016

Weidner 1914

Weidner 1915

Weidner 1923

Westenholz 1993

von Soden 1965
Giovanni Pettinato, "Il Calendario Semitico del 3. Millennio Ricostrutio sulla Base dei testi di Ebla”, Orien Antiquus 16, pp. 257-285.

Maciej Popko, Zippalanda, Ein Kultzentrum im hethitischen Kleinasien. Heidelberg: Universitätsverlag C. Winter, Texte der Hethiter 21.

Jaan Puhvel, Hittite Etymological Dictionary, H. Berlin, New York: Mouton de Gruyter.

Kaspar K. Riemschneider, Die akkadischen und hethitischen Omentexte aus Bogazköy. (DBH 12), Dresden: Verlag der Technische Universität Dresden.

Ergun Sarı, "İnsan Doğa İlişkilerinin Halk Takviminde Yansiması", Folklor 19, pp. 51-68.

Jana Siegelová, Appu-Marchen und Hedammu Mythus. Wiesbaden: Harrassowitz, StBoT 14.

Frank Starke, Die keilschrift-luwischen Texte in Umschrift. Wiesbaden: Harrassowitz, StBoT 30.

E. H. Sturtevant, "A Hittite Text on the Duties and Temple Servants", Journal of the American Oriental Society 54/4, pp.363-407.

Aygül Süel, Hitit Kaynaklarında Tapınak Görevlileri ile İlgili Bir Direktif Metni. Ankara: Ankara Üniversitesi Dil ve Tarih Coğrafya Fakültesi Yayınları.

Ada Taggar-Cohen, Hittite Priesthood. Heidelberg: Winter.

Johann Tischler, Hethitisches Handwörterbuch. Insbruck: Institut für Sprachen und Literaturen der Universität.

Ahmet Ünal, Hititçe-Türkçe, Türkçe-Hititçe Büyük Sözlük. Ankara: Bilgin Kültür Sanat Yayınları.

Ernst F. Weidner, "Die Sternliste von Boghaz-Köi”, Kampfe um den alten Orient 4, pp. 17-21.

Ernst F. Weidner, “Die Sternliste von Boghazköi”, Handbuch der babylonischen Astronomie 1, pp. 60-62.

Ernst F. Weidner, "Astrologische Texte aus Boghazköi. Ihre sprachliche und kulturhistorische Bedeutung”, Archiv für Keilschriftforschung 1, pp. 1-8.

Ulla Koch Westenholz, "Mesopotamian Astrology at Hattusas", Die Rolle der Astronomie in den Kulturen Mesopotamiens. Beiträge zum 3. Grazer Morgenländischen Symposium, September 23-27 1991, pp. 231-246.

Wolfram von Soden, Akkadisches Handwörterbuch, Band I. Wiesbaden: Otto Harrosowitz. 
Some Remarks about The Summer Period in Hittite Anatolia

von Schuler 1967 Einar von Schuler, Hethitische Diensteinweisungen für Hörere Hof- und Staatsbeamte. Osnabrück: Selbstverlage des Herausgebers.

Yakar 2007

Jak Yakar, Anadolu'nun Etnoarkeolojisi, Tunç ve Demir Çağlarında Kırsal Kesimin Sosyo-Ekonomik Yapısı, İstanbul: Homer Kitabevi ve Yayıncılık Ltd. Şti. 